\title{
Morphological and microsatellite analysis of the ancient Montenegrin olive variety 'Žutica' revealed different clones
}

\author{
Mirjana ADAKALIĆ ${ }^{1,2}$, Biljana LAZOVIĆ ${ }^{1}$, Alenka BARUCA ARBEITER ${ }^{3}$, Matjaž HLADNIK ${ }^{3}$, Jernej \\ JAKŠE $^{4}$, Dunja BANDELJ ${ }^{3}$
}

Received July 10, 2020; accepted September 17, 2020.

Delo je prispelo 10. julija 2020, sprejeto 17. september 2020.

\begin{abstract}
Morphological and microsatellite analysis of the ancient Montenegrin olive variety 'Žutica' revealed different clones

Abstract: The 'Žutica' represents the most common Montenegrin olive varieties mainly used for the production of olive oil and green and black fruit canning. Traditionally, the olive plants have been propagated vegetatively, and a small level of genetic polymorphism is expected among clones of the same variety. This topic was only partially studied in the Montenegrin olive 'Žutica'. Therefore, this study aimed to determine intravarietal genetic variability in twenty-three 'Žutica' trees selected in situ, analyzing the variability of morphological traits and microsatellites. The Principal Component Analyses (PCA) with six axes explains the total cumulative variance of $91.3 \%$, with fruit and endocarp traits in the first three PC. The unweighted pair group method with arithmetic mean of twenty morphological traits grouped 'Žutica' trees into two clusters and five independent trees. Nine microsatellite primers amplified 31 fragments of which 22 were polymorphic and enabled the detection of nine different microsatellite profiles (potential different clones). A comparison of dendrogram groups based on morphological and microsatellite markers showed low cophenetic values in the determination of intra-varietal variability. The results showed that the old variety 'Žutica', from a relatively small geographic region, has a variable genetic base, which could be used in the selection of superior clones.
\end{abstract}

Key words: intra-varietal variability; morphological characterization; PCA; microsatellites; 'Žutica'
Morfološka in mikrosatelitska analiza stare črnogorske sorte oljke 'Žutica' sta odkrili variabilnost klonov

Izvleček: Sorta 'Žutica' predstavlja najbolj pogosto zastopano črnogorsko sorto oljke, ki se uporablja za pridelavo oljčnega olja ter za vlaganje zelenih in obarvanih plodov. Tradicionalno se oljko razmnožuje vegetativno, zato je pričakovati majhen genetski polimorfizem med kloni iste sorte. To je bilo pri črnogorski sorti 'Žutica' le delno proučeno in je predmet te raziskave. Za določitev znotraj sortne genetske variabilnosti $\mathrm{z}$ analizo morfoloških lastnosti in mikrosatelitov je bilo izbranih 23 dreves. Analiza glavnih komponent (PCA) je s prvimi šestimi osmi pojasnila $91,3 \%$ celokupne variabilnosti, pri čemer so $\mathrm{k}$ vrednosti prvih treh osi najbolj prispevale lastnosti ploda in endokarpa. Združevanje z metodo netehtane aritmetične sredine na osnovi dvajsetih morfoloških lastnosti je drevesa 'Žutice' razvrstilo v dve skupini, pet dreves pa je ostalo nerazvrščenih. $\mathrm{Z}$ začetnimi oligonukleotidi za devet mikrosatelitskih lokusov se je pomnožilo 31 fragmentov, od katerih je bilo 22 polimorfnih, kar je omogočilo določitev devetih mikrosatelitskih profilov (potencialno različnih klonov). Pri primerjavi skupin iz dendrogramov, izdelanih na osnovi znotraj sortne variabilnosti morfoloških in mikrosatelitskih označevalcev, je bila ugotovljena majhna vrednost kofenetske korelacije. Rezultati so pokazali, da ima stara sorta 'Žutica', z relativno majhnega geografskega območja, raznoliko genetsko osnovo, kar bi lahko uporabili za izbor najboljših klonov.

Ključne besede: znotrajsortna raznolikost; morfološka karakterizacija; PCA; mikrosateliti; 'Žutica'

1 University of Montenegro, Biotechnical Faculty, Centre for Subtropical Cultures, Montenegro

2 Corresponding author, e-mail: adakalic@yahoo.com

3 University of Primorska, Faculty of Mathematics, Natural Sciences and Information Technologies, Department of Applied Natural Sciences. Koper, Slovenia

4 University of Ljubljana, Biotechnical Faculty, Agronomy Department, Ljubljana, Slovenia 


\section{INTRODUCTION}

The olive (Olea europaea L.) is one of the most important and the oldest fruit trees in the Mediterranean Basin, probably domesticated in Chalcolithic Levant (Zohary et al., 2012). Olive trees are grown to produce high-quality fruit for consuming oil and table consumption, but also wood and ornamental design in the natural landscapes.

The cultivated olive has a very wide genetic background and a high number of olive varieties (presumed clones) are grown throughout the world. Several hundred, assumed olive clones are described within the Mediterranean region (Figueiredo et al., 2013). The number of cultivated varieties in olive germplasm is reported in $\mathrm{Ol}-$ ive Germplasm Database (http://www.oleadb.it/olivodb. html). About 1,250 varieties in 54 countries conserved in over 100 collections, is probably an underestimate since there is a lack of information about local varieties, rarer cultivars widespread in the different olive growing areas. Indeed, a large number of synonyms (one genotype with several denominations) and homonyms (one denomination for several genotypes) in different areas of cultivation additionally hinder the identification of olive varieties (Caruso et al., 2014). That creates many complications in the classification of cultivated olive varieties due to the lack of standards reference variety (Figueiredo et al., 2013).

On the relatively small area of the East coast of the Adriatic sea bordered by Montenegro, olive cultivation has lasted for thousands of years. Nowadays, around 436,000 productive trees (MONSTAT, 2012) covering approximately 3,200 ha grow in this area (Lazović \& Adakalić, 2012a). The growing of traditional varieties prevails, characterized mainly by the cultivation of numerous ancient trees representing autochthonous olive germplasm composed of twelve main cultivated varieties. The Coastal area is divided into Bar and Boka Kotorska Bay subareas, mainly due to the relief structure and to the olive assortment. In the Southern part (municipalities of Ulcinj, Bar and Budva) the indigenous old variety 'Žutica' predominates with around $97 \%$ of total olive trees. In the area of Boka Kotorska Bay (municipalities of Tivat, Kotor and Herceg Novi) olive growing is based on 'Žutica' (36\%) and other varieties 'Crnica', 'Lumbardeška', 'Sitnica', ‘Šarulja', etc. (Miranović, 2006; Lazović \& Adakalić, 2012b; Lazović et al., 2014a).

During the long history of olive cultivation, polyclonality occurred and resulted in the formation of heterogeneous varieties (different genotypes or variety populations), and/or populations of clones (a mixture of clone variants) (Figueiredo et al., 2013; Caruso et al., 2014). Genetic variability of olive germplasm and intra-varietal diversity was reported in many olive varieties using morphological and molecular markers. Formerly, morphological and agronomical characterization had been widely used to evaluate diversity in the olive (Barranco et al., 2000; Cimato et al., 2001; Bassi et al., 2003; Rallo, 2005) with the addition of analyzing the data by PCA (Cantini et al., 1999; Trentacoste \& Puertas, 2011). The introduction of DNA markers provided a sound discriminatory system for varietal identification and intra-varietal polymorphism detection, independent of environmental conditions. Therefore, DNA molecular markers are today widely used to complement morphological analysis (Trujillo et al., 2014) and to identify clones unambiguously. Polyclonal olive varieties have been detected using RAPD and AFLP (Figueiredo et al., 2013; Strikić et al., 2011; Banilas et al., 2003; Bandelj, 2005; Sanz-Cortés et al., 2003) or combining different molecular markers (Belaj et al., 2004; Gemas et al., 2004; Gomes et al., 2008; Martins-Lopes et al., 2009). Microsatellites have been primarily used to detect intra-varietal polymorphism and to identify clones (Lopes et al., 2004; Taamalli et al., 2007; Omrani-Sabbaghi et al., 2007; Noormohammadi et al., 2009; Rony et al., 2009; Muzzalupo et al., 2009). The new promising genotypes or superior clones were identified by microsatellite markers and morphological traits (Caruso et al., 2014; Zaher et al., 2011; Marra et al., 2014). SNP markers have recently been used in the genotyping and detection of polymorphisms in olives, as well as their association with important agronomic traits (Kaya et al., 2016, 2019). Therefore, the identification of clones today is mainly based on the study of molecular genetics techniques integrated with morphological traits.

The selection of clones with desirable fruit and oil quality is required since the quality of table olives and olive oil is significantly affected by genotype (Ipek et al., 2012). Due to the available genetic diversity in the olive, it is essential to select the clones with desirable traits such as low vigour, tolerance/resistance to low temperatures, salinity (Muzzalupo et al., 2010), drought stress (Caruso et al., 2014), etc. Some of these objectives could be taken into account in future selection programs of desirable genotypes to promote olive growing in Montenegro.

'Žutica' is the old dual purpose variety with olive oil content higher than $20 \%$ and medium to large fruits in some trees. Those are advantages that could be implemented in the future olive growing and spreading of such clones. Previous research on intra-varietal variability in 'Žutica' was conducted by Lazović et al. (2002, 2016, 2018a). RAPD and SSR polymorphism was revealed, but the morphological properties of leaf, inflorescences, fruit and endocarp of the same clones were not analyzed. In some other researches, morpho-phenological and agronomic attributes (Lazović et al., 2014b, 2014c, 
2018b; Adakalić \& Lazović, 2018), as well as oil composition variability (Lazović et al., 2011; Adakalić \& Lazović, 2018) of different clones of 'Žutica' were recorded.

So, the purpose of this paper was to present the mutual analysis of the data conducted from our research on autochthonous ancient olive variety 'Žutica' with the following objectives: (i) to characterize the 'Žutica' olive variety by analyzing morphological traits, (ii) to evaluate the genetic variability within the variety using microsatellite markers and (iii) to compare the efficiency of morphological and microsatellite markers to indicate the remarkable clones.

\section{MATERIALS AND METHODS}

\subsection{PLANT MATERIAL}

Twenty-three olive trees (O. europaea L.) belonging to the 'Žutica' variety were studied. A larger number of samples from the Bar subarea were analyzed due to the higher representation in the cultivation of this olive variety in this subarea. Eighteen olive trees from Bar subarea are marked with codes: ZAV4, ZAV7, ZAV9, ZAV16, ZAV19, ZAV28, ZAV42, DAB1, DAB2, DAB3, DM5, SUS1, BARV, VALL, VAL2, PETR, REZ, IVA, and five olive trees from Boka Kotorska Bay coded: LUS14, LUS15, LUSM, GRB and HNSD. Sampling sites of collected olive material at two subareas are presented on the map (Fig $1)$.

\subsection{MORPHOLOGICAL CHARACTERIZATION}

To record the extent of morphological diversity over three growing seasons (from 2004 to 2008), a total of 20 morphological characters were studied based on olive descriptors (Barranco et al., 2000; EU/COI., 1997) recommendations. These included the characteristics of leaves (length-LL, width-LW and shape index-LI), internodes (length-INT), inflorescences (length-IL, number of flowers-NF, number of aborted flowers-NAF and percentage of aborted flowers-PAF, inflorescence density-ID), fruits (length-FL, width-FW, shape index -FI, mass-FM, pulp mass-PM and pulp percentage-PP) and endocarps (length-EL, width-EW, shape index -EI, mass-EM and pulp/endocarp ratio-P/E). Forty plant organ samples from the south-facing sides of trees were collected and characterized for each morphological measurement. Mean values, variability range, variation coefficient and minimum significant difference among analyzed characteristics for all parameters were reported.

\subsection{DNA EXTRACTION AND MOLECULAR ANALYSIS}

Total genomic DNA was isolated from fresh leaf material following the CTAB procedure described by Kump at al. (1992). DNA concentration was measured on a mini fluorometer TKO100 (Hoefer Scientific, San Francisco, USA) following the manufacturer's instructions. Nine microsatellite loci were tested using the following primer pairs: DCA3, DCA9, DCA11, DCA14 and DCA16 (Sefc et al., 2000), EMO3 and EMO90 (De la Rosa et al., 2002), GAPU101 (Carriero et al., 2002) and UDO99-19 (Cipriani et al., 2002). PCR amplifications were performed in a reaction volume of $10 \mu \mathrm{l}$ containing $1 \times$ PCR buffer (Promega, Manheim, Germany) [10 $\mathrm{mM}$ Tris- $\mathrm{HCl}\left(\mathrm{pH} 8,3\right.$ at $\left.20^{\circ} \mathrm{C}\right) ; 1,5 \mathrm{mM} \mathrm{MgCl}_{2} ; 50 \mathrm{mM}$

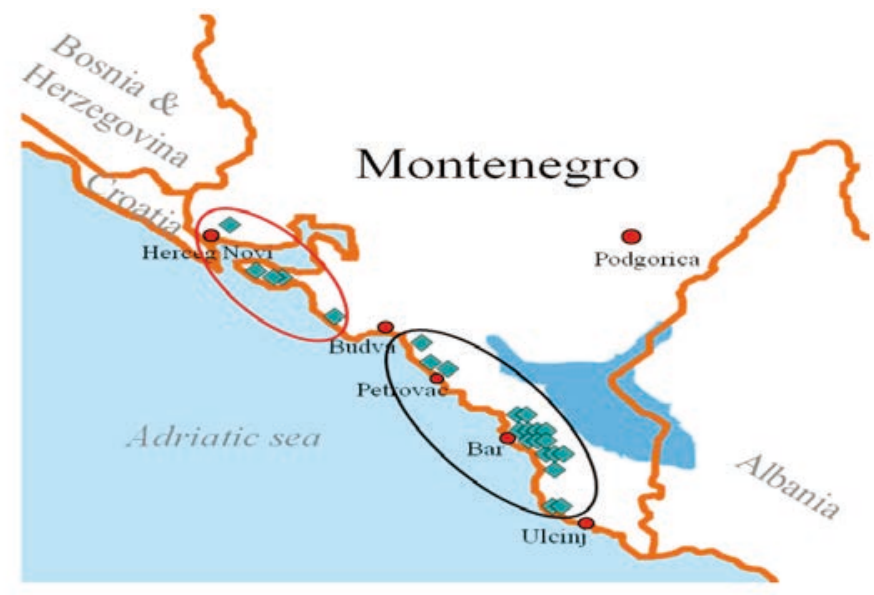

Figure 1: The Coastal area of Montenegro with two subareas, Bar (black ellipse) and Boka Kotorska Bay (red ellipse), showing the location of the 23 olive trees belonging to variety 'Žutica' examined. The green diamond symbol denotes sampling sites 
$\mathrm{KCl}$ ], $0.2 \mathrm{mM}$ of each dNTP (Sigma-ALDRICH, St. Louis, USA), $0.2 \mu \mathrm{M}$ initial concentration oligonucleotides, $0.25 \mu \mathrm{M}$ universal M13(-21) (TGTAAAACGACGGCCAGT) primer (Schuelke, 2000), marked with fluorescent molecule FAM, VIC, PET or NED (Applied Biosystems), 0.25 U Taq polymerase (Promega, Manheim, Germany) and 20 ng of olive DNA. Amplifications were performed following the protocol of Bandelj et al. (2004) in a Thermal Cycler 2720 (Applied Biosystems), using the following cycling conditions: initial denaturation at $94^{\circ} \mathrm{C}$ for 5 min followed by 5 cycles of $45 \mathrm{~s}$ at $94^{\circ} \mathrm{C}, 30 \mathrm{~s}$ at $57^{\circ} \mathrm{C}$, $30 \mathrm{~s}$ at $72^{\circ} \mathrm{C}$ (the annealing temperature was lowered for $1{ }^{\circ} \mathrm{C}$ with each cycle), followed by 25 cycles of $30 \mathrm{~s}$ at $94{ }^{\circ} \mathrm{C}, 30 \mathrm{~s}$ at $52^{\circ} \mathrm{C}, 1.5 \mathrm{~min}$ at $72^{\circ} \mathrm{C}$ and final extension step of $8 \mathrm{~min}$ at $72{ }^{\circ} \mathrm{C}$. The resulting PCR products were separated on an ABI Prism 3130 DNA Genetic Analyzer (Applied Biosystems). Output data were analyzed using GeneMapper 4.1 software (Applied Biosystems).

\subsection{DATA ANALYSIS}

To determine the significant differences between examined olive trees, 20 morphological parameters were analyzed, and the ANOVA LSD test was used, with a threshold of $p<0.05$, using the software Statistix 7.0 (General AOV, Florida, USA). The data were standardized and Principal Component Analysis (PCA) was performed and the scatter plot of the principal component according to variables and individuals was performed. Hierarchical cluster analysis was carried out using the unweighted pair group method using arithmetic average (UPGMA) and the dendrogram was created using the squared Euclidean distance as the similarity coefficient. The analyses were performed using the statistical software XLSTAT (Version 2015.5.01.22537).

Allele frequencies $\left(\mathrm{p}_{i}\right)$, number of effective alleles $\left(\mathrm{n}_{\mathrm{e}}\right)$, observed $(\mathrm{Ho})$ and expected $(\mathrm{He})$ heterozygosity, fixation index $(F)$ were analyzed by using GenAlEx 6.4 (Peakall \& Smouse, 2006). Presence of null alleles $(r)$ was calculated in IDENTITY 1.0 (Wagner \& Sefc, 1999), Polymorphism Information Content (PIC) in CERVUS 3.0.3 (Kalinowski et al., 2007) and genotype specific alleles in MICROSAT 1.5 (Minch, 1997). Microsatellite polymorphisms were scored for the presence (1) or absence (0) of amplified bands and were used for estimation of the

Table 1: Analysis of 20 morphological characteristics evaluated in this study in 23 'Žutica' trees

\begin{tabular}{|c|c|c|c|c|c|}
\hline Morphological characters & Maximum & Minimum & Average & $\mathrm{CV}(\%)^{\mathrm{a}}$ & LSD $^{\mathrm{b}} p$-value \\
\hline Leaf length - LL (cm) & 6.40 & 4.86 & 5.81 & 8.020 & $0.0710 \mathrm{~ns}$ \\
\hline Leaf width - LW (cm) & 1.39 & 1.13 & 1.25 & 8.399 & $0.0009^{* *}$ \\
\hline Leaf shape index - LI (LL/LW) & 5.16 & 4.26 & 4.63 & 11.758 & $0.2187 \mathrm{~ns}$ \\
\hline Internodes length - INT (cm) & 1.75 & 1.12 & 1.52 & 18.118 & $0.0016^{\star *}$ \\
\hline Inflorescence length - IL (cm) & 3.06 & 1.57 & 2.51 & 16.972 & $0.0000^{\star *}$ \\
\hline Number of flowers - NF & 21.05 & 8.63 & 13.68 & 19.226 & $0.0000^{* *}$ \\
\hline Number of aborted flowers - NAF & 8.09 & 1.47 & 2.92 & 67.061 & $0.0064^{\star *}$ \\
\hline Percent of aborted flowers - PAF (\%) & 38.45 & 10.29 & 20.98 & 58.364 & $0.1717 \mathrm{~ns}$ \\
\hline Inflorescence density - ID (NF/IL) & 6.94 & 4.81 & 5.45 & 13.637 & $0.0181^{\star}$ \\
\hline Fruit length - FL (cm) & 2.35 & 1.78 & 2.12 & 7.823 & $0.0026^{\star *}$ \\
\hline Fruit width - FW (cm) & 1.72 & 1.40 & 1.57 & 7.339 & $0.0067^{\star *}$ \\
\hline Fruit shape index - FI (FL/FW) & 1.53 & 1.23 & 1.33 & 6.726 & $0.0011^{\star *}$ \\
\hline Fruit mass - FM (g) & 4.28 & 2.02 & 3.11 & 18.972 & $0.0000^{* *}$ \\
\hline Pulp mass - PM (g) & 3.72 & 1.76 & 2.71 & 19.873 & $0.0000^{\star *}$ \\
\hline Pulp percentage - PP (\%) & 89.33 & 84.39 & 87.08 & 2.430 & $0.0393^{\star}$ \\
\hline Endocarp length - EL (cm) & 1.55 & 1.16 & 1.38 & 8.631 & $0.0048^{\star *}$ \\
\hline Endocarp width - EW (cm) & 0.81 & 0.63 & 0.72 & 8.012 & $0.0007^{\star *}$ \\
\hline Endocarp shape index - EI (EI/EW) & 2.28 & 1.69 & 1.90 & 8.549 & $0.0000^{* *}$ \\
\hline Endocarp mass - EM (g) & 0.56 & 0.28 & 0.40 & 19.704 & $0.0438^{\star}$ \\
\hline Pulp/endocarp ratio - P/E & 8.37 & 5.41 & 6.83 & 17.679 & $0.0200^{*}$ \\
\hline
\end{tabular}

${ }^{\text {a }}$ Coefficient of variance expressed in percentage.

${ }^{\mathrm{b}}$ LSD Least Significant Difference test, $p$-values are ${ }^{*}$ Significant at $p>0.01$; ${ }^{\star}$ Significant at $p>0.05$; ns-not significant $(p<0.05)$. 
Dice similarity coefficients between clones. This genetic distance matrix was used to construct a dendrogram by using the UPGMA method in NTSYS 2.0 (Rohlf, 1998) software. The cophenetic value matrix of the clustering was used to test for the goodness of fit of the clustering to the similarity matrix by the Mantel statistics in the COPH and MXCOMP modules of NTSYS 2.0 (Rohlf, 1998) software.

\section{RESULTS AND DISCUSSION}

\subsection{MORPHOLOGICAL CHARACTERISTICS}

In terms of 20 morphological characteristics, there is a great amount of variation among the 23 olive trees analyzed. The morphological traits (Table 1 and Fig. 2) showed that 'Žutica' had moderately long internodes (EU/COI., 1997). According to the evaluation of Barranco et al. (2000) 'Žutica' had_a leaf of medium length and width and elliptic-lancelet shape, medium length inflorescence, with a small number of flowers in the inflorescence and the medium number and percentage of aborted flowers in an inflorescence. Based on the mean inflorescence density, 'Žutica' represents a variety with a medium length and loose inflorescence (Cimato et al., 2001; Bassi et al., 2003). According to the methodology of Barranco et al. (2000) along with the variety, various environmental and agronomic factors influence the phenomenon of malformations of the female apparatus. Regarding that, 'Žutica' belongs to a category of medium percent of pistil abortion (20-60\%). Based on the same methodology the form of fruit was oval and of endocarp elliptic. The mean mass of the fruit and endocarp (3.11 and $0.40 \mathrm{~g}$ respectively) resulted in a favorable pulp mass $(2.71 \mathrm{~g})$, percentage $(87.08 \%)$ and the ratio of the pulp/ endocarp (6.83). The favorable pulp/endocarp ratio upward of 6 (Barone et al., 1993) had $78.2 \%$ of 'Žutica' trees.

All 20 morphological characteristics were included in the analysis of principal components (PCA) of morphological variability. The first four main components make up $78.7 \%$ of the cumulative total variance, while six components explain $91.3 \%$ of the variation. The eigenvalue of the components constitutes $30.2 \%, 23.5 \%$, $13.1 \%, 11.7 \%, 6.7 \%$ and $5.7 \%$ of the total variance among the average values of the morphological characteristics of the studied 'Žutica' trees (Table 2 and Fig. 3 ). The first two or three components provide good data summation and separation of traits that mostly affect the clustering of the examined trees. The clustering was influenced by the properties of PC1 (FL, FW, FM, EL, EW, EM and PM), PC2 (FI and FE) and PC3 (LI, INT, PP and $\mathrm{P} / \mathrm{E}$ ), while some characteristics of the leaf (LL and LW) and all inflorescence traits were less important in grouping the trees into clusters belonging to the PC4, PC5 and PC6 component. Affiliation of fruit and endocarp characteristics (length, width and mass) in PC1 has been reported by several authors. In various olive varieties in Montenegro (Lazović \& Adakalić, 2012b), Italy (Cantini et al., 1999), Argentina (Trentacoste \& Puertas, 2011) and the Croatian variety 'Oblica' (Strikić et al., 2009), characteristics of fruit and endocarp mostly contribute to the grouping of analyzed individuals into clusters.

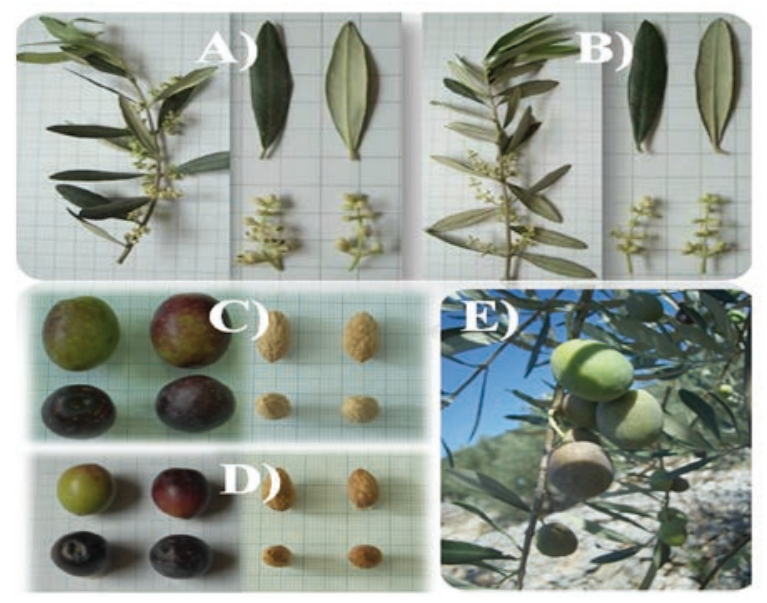

Figure 2: Vegetative and generative organs of some 'Žutica' trees: A) olive inflorescences with the lowest average inflorescence density (ID) determined in VALL (located nearby Ulcinj); B) olive twig with the longest internodes (INT) determined in PETR (Petrovac); C) fruit and endocarp of 'Žutica' tree coded VAL2 (nearby Ulcinj), which has the greatest values of fruit and endocarp mass (FM and EM); D) fruit and endocarp of DAB1 (nearby Bar), with the least values of fruit and endocarp mass; E) twig of LUSM (Lustica) with a few fruits. 
Table 2: Total variance, cumulative variance and eigenvalues of the first six main components (PC) for 20 characteristics in 23 'Žutica' trees

\begin{tabular}{|c|c|c|c|c|c|c|}
\hline Morphological characters & PC1 & PC2 & PC3 & PC4 & PC5 & PC6 \\
\hline Leaf length - LL (cm) & -0.170 & 0.213 & 0.258 & 0.026 & 0.892 & -0.085 \\
\hline Leaf width - LW (cm) & -0.095 & -0.180 & -0.453 & 0.068 & 0.797 & 0.171 \\
\hline Leaf shape index - LI (LL/LW) & -0.091 & 0.392 & 0.730 & -0.041 & 0.077 & -0.254 \\
\hline Internodes length - INT (cm) & 0.180 & 0.061 & -0.627 & -0.001 & 0.401 & 0.538 \\
\hline Inflorescence length - IL (cm) & 0.284 & 0.180 & 0.084 & -0.141 & 0.011 & 0.909 \\
\hline Number of flowers - NF & 0.217 & 0.079 & 0.092 & 0.442 & -0.007 & 0.819 \\
\hline Number of aborted flowers - NAF & 0.063 & 0.137 & 0.173 & 0.910 & 0.085 & 0.248 \\
\hline Percent of aborted flowers - PAF (\%) & -0.039 & 0.176 & 0.194 & 0.889 & 0.066 & -0.094 \\
\hline Inflorescence density - ID (NF/IL) & -0.068 & -0.128 & 0.043 & 0.867 & -0.073 & -0.040 \\
\hline Fruit length - FL (cm) & 0.855 & -0.473 & -0.041 & 0.015 & 0.037 & 0.068 \\
\hline Fruit width - FW (cm) & 0.866 & 0.252 & 0.201 & 0.145 & 0.075 & 0.148 \\
\hline Fruit shape index - FI (FL/FW) & 0.074 & -0.878 & -0.279 & -0.122 & -0.007 & -0.093 \\
\hline Fruit mass - FM (g) & 0.881 & -0.033 & 0.341 & 0.043 & -0.108 & 0.254 \\
\hline Pulp mass - PM (g) & 0.853 & -0.024 & 0.406 & 0.069 & -0.104 & 0.253 \\
\hline Pulp percentage - PP (\%) & 0.208 & 0.114 & 0.890 & 0.238 & 0.026 & 0.193 \\
\hline Endocarp length - EL (cm) & 0.684 & -0.632 & -0.117 & -0.117 & -0.140 & -0.118 \\
\hline Endocarp width - EW (cm) & 0.843 & 0.412 & -0.071 & -0.039 & -0.078 & 0.035 \\
\hline Endocarp shape index - EI (EI/EW) & -0.117 & -0.941 & -0.067 & -0.056 & -0.050 & -0.148 \\
\hline Endocarp mass - EM (g) & 0.862 & -0.095 & -0.295 & -0.179 & -0.148 & 0.187 \\
\hline Pulp/endocarp ratio - $\mathrm{P} / \mathrm{E}$ & 0.184 & 0.135 & 0.894 & 0.266 & 0.009 & 0.162 \\
\hline Eigenvalue & 6.049 & 4.711 & 2.637 & 2.355 & 1.356 & 1.155 \\
\hline Total variance (\%) & 30.245 & 23.554 & 13.187 & 11.774 & 6.780 & 5.777 \\
\hline Cumulative variance (\%) & 30.245 & 53.800 & 66.987 & 78.761 & 85.541 & 91.318 \\
\hline
\end{tabular}
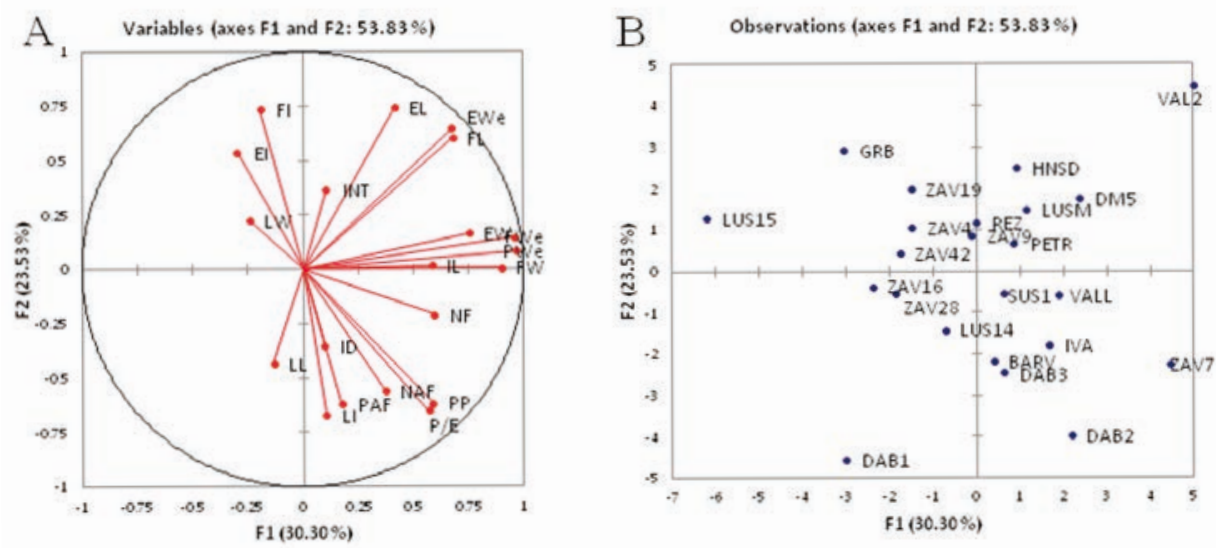

Figure 3: A: The scatter plot of the first two principal components (characteristics labels correspond to those in section 2.2 'Morphological characterization'); B: The scatter plot of 23 'Žutica' trees according to the plan generated by 1-2 axes of PCA (tree codes correspond to those in section 2.1 'Plant material'). 
Based on morphological characteristics, the trees were grouped into two clusters (Fig. 4) and five independent individuals (DAB1, LUS15, GRB, ZAV7 and VAL2). Very good matching of the morphological traits in the grouping of 'Žutica' trees in the clusters by using the squared Euclidean distance was confirmed by the high value of the cophenetic coefficient $\left(\mathrm{r}_{\text {morph }}=0.91985\right)$. The clustering of 'Žutica' trees according to the fruit size was determined, and a partial clustering according to the geographical distribution. Trees belonging to the second cluster (DAB2, BARV, LUS14, DAB3, IVA, SUS1, VALL, DM5, HNSD and LUSM) had higher average values of fruit and pulp mass (3.35 and $2.95 \mathrm{~g}$ respectively), pulp percentage $(88.20 \%)$, and pulp/endocarp ratio (7.50) versus the first cluster. The great importance of fruit characteristics is also shown by the analysis of the principal components. Grouping of the trees according to the size of the fruit (Rotondi et al., 2003) indicates that the selection of clones in the past appears to be carried out according to this feature. The first cluster consists of eight trees (ZAV4, ZAV42, ZAV28, ZAV9, ZAV19, ZAV16, REZ and PETR) grown in the Bar subarea, and the second cluster includes ten trees grown in both olive growing areas, in Bar and Boka Kotorska Bay subareas. Contrary to our results, in the study on intra-varietal variability of Iranian varieties 'Zard' and 'Rowghani' (Hosseini-Mazinani et al., 2004) and Croatian 'Oblica' from several growing areas (Strikić et al., 2009), the authors did not find the grouping of individuals surveyed by areas of cultivation.

According to specific morphological characteristics (min. or max. values), five trees were separated from all 'Žutica' trees evaluated. Thus, DAB1 is characterized by the lowest values of some fruit and endocarp traits (FL, EL, EW and EM) and LUS15 by the lowest values of the internodes (INT), inflorescence (IL and NF) and fruit and endocarp (FW, FM, PM, PP and P/E) characteristics. GRB differs from other trees at the highest values of fruit and endocarp form (FI and EI). ZAV7 had the longest internodes (INT), the highest values of almost all inflorescence traits (NF, ID, NAF and PAF) and one fruit characteristics (FW), while VAL2 had the longest inflorescence (IL), the highest values of fruit and endocarp length and mass (FL, FM, EL, EM) and pulp mass (PM).

Very significant differences in morphological characteristics, especially in fruit characteristics, found in 'Žutica' trees indicate the need to form collections of these trees and study their characteristics under the same agroecological conditions. In such conditions, it would be of great importance to include these trees in further observation and study of other differences, such as productivity, olive oil quality, resistance, etc.

\subsection{MICROSATELLITES ANALYSIS}

With nine pairs of locus specific microsatellite primers, a total of 31 alleles (22 polymorphic and 9 monomorphic) were found in the 23 trees of 'Žutica' analyzed. Among the monomorphic alleles, allele $132 \mathrm{bp}$ at the UDO99-19 locus was present in all 'Žutica' samples therefore this locus was excluded from further analysis (Table 3). The average number of alleles per each locus was 3.75 , ranging from 2 at loci DCA14 and EMO3 to 7 at loci DCA9 and DCA11. These values are lower than the number of alleles detected by Lopes et al. (2004) and Caruso et al. (2014), but slightly higher than those detected by Muzzalupo et al. (2009) and Lazović et al. (2018a). The information value of the locus also depends on the frequency

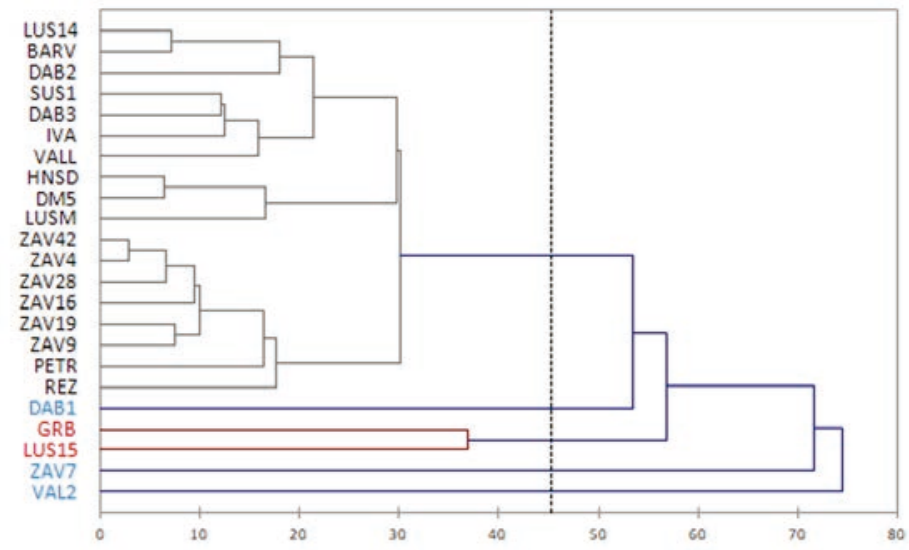

Figure 4: UPGMA dendrogram of 23 'Žutica' trees derived from 20 morphological traits. The dendrogram shows two clusters (black line and code colour) and five independent individuals (blue line and code colour) that include a pair of individuals with more or less similar morphological characteristics (red line and code colour). 
of alleles, therefore the number of effective alleles was calculated, which differed from the actual number of alleles, and on average it was 2.21 per locus. The average observed heterozygosity $\left(\mathrm{H}_{\mathrm{o}}\right)$ was 1,000 , therefore no homozygous genotypes were observed. The average expected heterozygosity $\left(\mathrm{H}_{\mathrm{e}}\right)$ was 0.542 , ranging from 0.500 (DCA14 and EMO3) to 0.635 (DCA9). Similarly expected heterozygosity ( 0.57 and 0.41 respectively) has also been reported by Noormohammadi et al. (2009) and Rony et al. (2009) and higher values (0.67) by Lopes et al. (2004) in the studies of inter- and intra-cultivar variations. The tendency of higher observed $\left(\mathrm{H}_{\mathrm{o}}\right)$ than expected $\left(\mathrm{H}_{\mathrm{e}}\right)$ heterozygosity in all loci, is reflected in the negative fixation index $(F)$ values, similar to the finding of Baldoni et al. (2009). Negative values of fixation index (average -0.860) resulted in the absence of null alleles $(r)$ at all loci and it was on average -0.299. Contrary to our results, Lopes et al. (2004) recorded higher values of the expected than the observed heterozygosity for the locus DCA11 and the positive values of the probability of null alleles. Polymorphic information content (PIC), as a significant parameter of genetic diversity, refers to the informativeness of a particular locus. PIC values are derived from the frequency of alleles and are used as a benchmark for the use of locus for genetic mapping. In this study of genetically close plant material, the loci DCA9 and DCA11 could be included among the informative (PIC > 0.5). The PIC values varied from 0.375 (DCA14 and EMO3) to 0.567 (DCA9), with an average value of 0.435 . In the study of clonal variation within the eight Sicilian cultivars, authors reported an average PIC value of 0.59 Caruso et al. (2014), and 0.51 within three Iranian cultivars (Noormohammadi et al., 2009).

Based on the presence (1) or absence (0) of a particular allele, a binary matrix was constructed, and Dice's coefficients of similarity were calculated. The very good similarity of the original data with the clustering of sam- ples using the microsatellite markers confirms the calculation of the correlation coefficient between the cophenetic and the Dice's coefficients values in the amount of $r_{\text {SSR }}=$ 0.98768. A dendrogram was constructed (Fig. 5) in which the 'Žutica' trees were grouped into 13 identical clones and 10 others with more or less genetic similarities. The greatest closeness (0.941) with this group had ZAV9, DAB3, IVA, DM5, and two pairs of DAB2 - VALL and SUS1 REZ which had the same microsatellite profiles at this loci and ZAV19 on a higher genetic distance (0.882). The VAL2 coded olive tree has the lowest genetic similarity (0.619) to 'Žutica'. For this tree, Lazović et al. (2018a) suggest that the most likely is a putative seedling of 'Žutica'. This genetically most distant sample was different from the group of identical microsatellite profiles on 6 loci (8 alleles). Eight trees (ZAV9, DAB2, DAB3, DM5, SUS1, VALL, REZ and IVA) differ in one allele, and one tree (ZAV19) differs in two alleles from the group of identical microsatellite profiles. In the study of intra-varietal variability of Italian olive varieties, Cipriani et al. (2002) found differences in the lengths of alleles in one or two loci that were explained by somatic mutations, while Lopes et al. (2004) found the differences in 'Galega' represented with 1-2 to 10 different alleles. Simple sequence repeats (SSR) are reported as a very suitable tool for intra-varietal analysis (Caruso et al., 2014; Lopes et al., 2004). Based on the microsatellite analysis, no grouping according to the size of the fruit or geographic origin was observed, referring to a possible exchange of planting material among local producers in these areas during the long cultivation of olives in Montenegro.

\subsection{COMPARISON BETWEEN MORPHOLOGICAL AND MOLECULAR MARKERS}

Mantel's matrix correspondence test after 1.000 per-

Table 3: Genetic variability parameters of microsatellite loci in 23 'Žutica' trees: observed (Ho) and expected (He) heterozygosity, number of alleles (n), number of effective alleles (ne), polymorphism information content (PIC), fixation index $(F)$ and presence of null alleles $(r)$.

\begin{tabular}{llllllll}
\hline Locus & $\mathrm{H}_{\mathrm{o}}$ & $\mathrm{H}_{\mathrm{e}}$ & $\mathrm{n}$ & $\mathrm{n}_{\mathrm{e}}$ & $\mathrm{PIC}$ & $F$ & $\mathrm{r}$ \\
\hline DCA3 & 1.000 & 0.521 & 3 & 2.09 & 0.406 & -0.920 & -0.315 \\
DCA9 & 1.000 & 0.635 & 7 & 2.74 & 0.567 & -0.574 & -0.223 \\
DCA11 & 1.000 & 0.614 & 7 & 2.59 & 0.541 & -0.628 & -0.239 \\
DCA14 & 1.000 & 0.500 & 2 & 2.00 & 0.375 & -1.000 & -0.333 \\
DCA16 & 1.000 & 0.521 & 3 & 2.09 & 0.406 & -0.920 & -0.315 \\
EMO3 & 1.000 & 0.500 & 2 & 2.00 & 0.375 & -1.000 & -0.333 \\
EMO90 & 1.000 & 0.521 & 3 & 2.09 & 0.406 & -0.920 & -0.315 \\
GAPU101 & 1.000 & 0.521 & 3 & 2.09 & 0.406 & -0.920 & -0.315 \\
\hline Mean & 1.000 & 0.542 & 3.75 & 2.21 & 0.435 & -0.860 & -0.299 \\
\hline
\end{tabular}




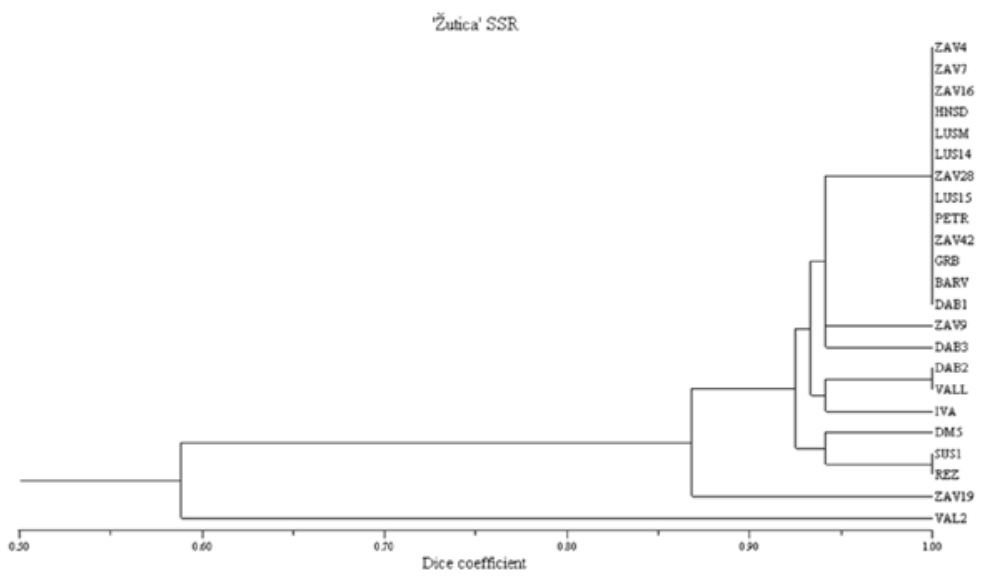

Figure 5: UPGMA dendrogram based on the results of microsatellite markers constructed according to the Dice coefficient of similarity in 23 'Žutica' trees

mutations was used to compare the distance matrices based on morphological traits and microsatellite markers. The correlation coefficient between the matrix based on morphological traits and microsatellite markers was relatively low $\left(\mathrm{r}_{\mathrm{n}}\right.$ $\left.{ }_{S S R}=0.17743\right)$. Such results are in favour of the fact that the morphological traits are largely under the influence of different environmental factors concerning the genetic basis of each individual, and for the detailed characterization of olive varieties, it is necessary to apply DNA analysis of polymorphism.

In our analysis, the sample VAL2 differs the most from others in terms of morphological and molecular markers. In addition to this tree, differentiation with microsatellite markers has been established in another nine trees. Six of them (DAB3, DAB2, VALL, IVA, DM5 and SUS1) belong to another cluster based on morphological traits, separated by higher average values of characteristics of fruit and pulp. The other three trees that are different from microsatellite analysis had some differences in the characteristics of leaves. Thus, ZAV9 had the smallest leaf shape index (LI), REZ maximum leaf width (LW) and ZAV19 without extreme values.

Each marker system measures different aspects of variability and this can explain the lack of consistency in genetic diversity and studies within the variety. The detected DNA variation, which is neutral, was often not correlated to the phenotypic and agronomical variation of olive varieties (Rao et al., 2009). However, despite the powerfulness of microsatellite markers to detect genetic variability and genetic relationships, they should not be seen as a substitute for traditional morpho-agronomic descriptors (Cantini et al., 2008).

\section{CONCLUSIONS}

In this paper, we have found morphological differenc- es among investigated trees of the 'Žutica' olive variety, and microsatellite analysis allowed us the differentiation of 9 different profiles. In assessing the genetic variability of 'Žutica' trees, low morphological efficacy compared to molecular markers was recorded, which is confirmed by the low values of the cophenetic coefficients. Based on the established polymorphism of morphological and molecular markers, we can conclude that the main microsatellite profile was defined, but some differences point to a certain degree of genetic variability. That needs further examination with a larger number of individuals in situ and ex situ (in the olive collection) under the equal ecological/environmental factors. These results show great genetic diversity within 'Žutica' samples that should be preserved and further evaluated for the identification of distinct properties of defined genotype. This is a springboard for phenotyping for future research on potential resistance to diseases, pests, and abiotic stresses, olive oil quality improvement, and for breeding efforts to introduce clones with the desired traits Accordingly, the results show that old olive varieties that are analyzed by different marker systems enable a more complete understanding of the diversity within the olive varieties and the ways they can best be used for the selection of new genotypes, olive breeding and conservation strategies to improve olive growing in Montenegro.

\section{REFERENCES}

Adakalić, M., \& Lazović, B. (2018). Morphological, chemical and molecular characterization of 'Old olive' (Olea europaea L.) from Montenegro. Brazilian Archives of Biology and Technology, 61. e18170767. https://dx.doi.org/10.1590/1678-43242018170767

Baldoni, L., Cultrera, N.G., Mariotti, R., Riccioloni, C., Arcioni, S., Vendramin, G.G., ... Testolin, R. (2009). A consensus list of microsatellite markers for olive genotyping. Molecular 
Breeding, 24, 213-231. https://doi.org/10.1007/s11032009-9285-8

Bandelj Mavsar, D. (2005). Analiza genetske variabilnosti oljke (Olea europaea L.) z molekulskimi markerji. Ljubljana: Univerza v Ljubljani. Biotehniška fakulteta. Odd. za agronomijo. Doktorska disertacija.

Bandelj, D., Jakše, J., Javornik, B. (2004). Amplification of fluorescent-labelled microsatellite markers in olives by a novel, economic method. Acta agriculturae Slovenica, 83(2), 323329.

Banilas, G., Minas, J., Gregoriou, C., Demoliou, C., Kourti, A., Hatzopoulos, P. (2003). Genetic diversity among accessions of an ancient olive variety of Cyprus. Genome, 46(3), 370376. https://doi.org/10.1139/g03-011

Barone, E., Caruso, T., Marra, F.P., Motisi, A. (1993). Caratteristiche biometriche di 25 cultivar di olivo del germoplasma siciliano. Atti Convegno "Tecniche. norme e qualita in olivicoltura”. Potenza, Italy. (pp. 623-630).

Barranco, D., Cimato, A., Fiorino, P., Rallo, L., Touzani, A., Castañeda, C., ... Trujillo I. (2000). World Catalogue Of Olive Varieties. Internation Olive Oil Council. Madrid, (pp. 360).

Bassi, D. (2003). Il Germoplasma dell'Olivo in Lombardia. Regione Lombardia. Università degli Studi di Milano, Italy. (pp. 88).

Belaj, A., Rallo, L., Trujillo, I., Baldoni, L. (2004). Using RAPD and AFLP Markers to Distinguish Individuals Obtained by Clonal Selection of 'Arbequina' and 'Manzanilla de Sevilla' Olive. HortScience, 39(7), 1566-1570

Cantini, C., Cimato, A., Autino, A., Redi, A., Cresta, M. (2008). Assessment of the Tuscan Olive Germplasm by Microsatellite Markers Reveals Genetic Identities and Different Discrimination Capacity among and within Cultivars. Journal of the American Society for Horticultural Science, 133(4), 598-604. https://doi.org/10.21273/JASHS.133.4.598

Cantini, C., Cimato, A., Sani, G. (1999). Morphological evaluation of olive germplasm present in Tuscany region. Euphytica, 109, 173-181. https://doi.org/10.1023/A:1003728800464

Carriero, F., Fontanazza, G., Cellini, F., Giorio, G. (2002). Identification of simple sequence repeats (SSRs) in olive (Olea europaea L.). Theoretical and Applied Genetics, 104(2-3), 301-307. http://dx.doi.org/10.1007/s001220100691

Caruso, T., Marra, F.P., Costa, F., Campisi, G., Macaluso, L., Marchese, A. (2014). Genetic diversity and clonal variation within the main Sicilian olive cultivars based on morphological traits and microsatellite markers. Scientia Horticulturae, 180, 130-138. https://doi.org/10.1016/j.scienta.2014.10.019

Cimato, A., Cantini, C., Sani, G. (2001). Lolivo in Toscana: il germoplasma autoctono. A.R.S.I.A., Regione Toscana, Istituto sulla Propagazione delle Specie Legnose-CNR. 218.

Cipriani, G., Marrazzo, M.T., Marconi, R., Cimato, A., Testolin, R. (2002). Microsatellite markers isolated in olive (Olea europaea L.) are suitable for individual fingerprinting and reveal polymorphism within ancient cultivars. Theoretical and Applied Genetics, 104(2-3), 223-228. http://dx.doi. org/10.1007/s001220100685

De la Rosa, R., James, C.M., Tobutt, K.R. (2002). Isolation and characterization of polymorphic SSRs in olive (Olea euro- paea L.) and their transferability to other genera in the Oleaceae. Molecular Ecology Notes, 2(3), 265-267. https://doi. org/10.1046/j.1471-8286.2002.00217.x

EU/COI, Consejo Oleícola Internacional. (1997). Methodology for primary and secondary characterization of olive varieties. Project RESGEN-CT (67/97).

Figueiredo, E., Canhoto, J., Ribeiro, M.M. (2013). Fingerprinting and genetic diversity of Olea europaea L. ssp. europaea accessions from the cultivar Galega using RAPD markers. Scientia Horticulturae, 156, 24-28. https://doi. org/10.1016/j.scienta.2013.03.011

Gemas, V.J.V., Almadanim, M.C., Tenreiro, R., Martins, A., Fevereiro, P. (2004). Genetic diversity in the Olive tree (Olea europaea L. subsp. europaea) cultivated in Portugal revealed by RAPD and ISSR markers. Genetic Resources and Crop Evolution, 51, 501-511. https://doi.org/10.1023/ B:GRES.0000024152.16021.40

Gomes, S., Martins-Lopes, P., Lima-Brito, J., Meirinhos, J., Lopes, J., Martins, A., Guedes-Pinto, H. (2008). Evidence of clonal variation in olive 'Verdeal-Transmontana' cultivar using RAPD, ISSR and SSR markers. The Journal of Horticultural Science and Biotechnology, 83, 395-400. https://doi. org/10.1080/14620316.2008.11512397

Hosseini-Mazinani, S.M., Mohammadreza Samaee, S., Sadeghi, H., Caballero, J.M. (2004). Evaluation of Olive Germplasm in Iran on the Basis of Morphological Traits: Assessment of 'Zard' and 'Rowghani' Cultivars. Proc. XXVI IHC-IVth Int. Symp. Taxonomy of Cultivated Plants. Acta Horticulturae, 634, 145-151. https://doi.org/10.17660/ActaHortic.2004.634.17

Ipek, A., Barut, E., Gulen, H., Ipek M. (2012). Assessment of inter- and intra-cultivar variations in olive using SSR markers. Scientia Agricola, 69(5), 327-335. https://dx.doi. org/10.1590/S0103-90162012000500007

Kalinowski, S.T., Taper, M.L., Marshall, T.C. (2007). Revising how the computer program CERVUS accommodates genotyping error increases success in paternity assignment. Molecular Ecology, 16(5), 1099-1106. https://doi.org/10.1111/ j.1365-294X.2007.03089.x http://en.bio-soft.net/other/ CERVUS.html

Kaya, H., Cetin, O., Kaya, H., Sahin, M., Sefer, F., Tanyolac, B. (2016). Association Mapping in Turkish Olive Cultivars Revealed Significant Markers Related to Some Important Agronomic Traits. Biochemical Genetics, 54. https://doi. org/10.1007/s10528-016-9738-9

Kaya, H., Akdemir, D., Lozano, R., Cetin, O., Kaya, H., Sahin, M., Smith, J., Tanyolac, B., Jannink, J-Luc. (2019). Genome wide association study of 5 agronomic traits in olive (Olea europaea L.). Scientific Reports, 9. https://doi.org/10.1038/ s41598-019-55338-w

Kump, B., Svetek, S., Javornik, B. (1992). Izolacija visokomolekularne DNK iz rastlinskih tkiv. Zbornik Biotehniške fakultete, 59, 63-66. Univerza v Ljubljani

Lazović, B., \& Adakalić, M. (2012a). Following olive footprints in Montenegro. In: El-Kholy. M. editor. Following Olive Footprints (Olea europaea L.): Cultivation and Culture. Folklore and History. Traditions and Uses. Scripta Horticulturae. N.13. AARINENA, IOC and ISHS. (pp. 254-265). Lazović, B., \& Adakalić, M. (2012b). Važnije karakteristike za 
razlikovanje autohtonih sorti masline (Olea europaea L.) iz Crne Gore. Zbornik znanstvenih prispevkov z mednarodnega posveta 'Novi raziskovalni pristopi u oljkarstvu", Univerzitetna Založba Annales, editor. (pp. 23-32).

Lazović, B., Adakalić, M., Ljutica, S., Perović, T. (2014c). Variability of oil content in fruit of olive variety Zutica on Montenegrin Coast. Agro-knowledge Journal, 15(1), 55-63. http://dx.doi.org/10.7251/AGREN1401055L

Lazović, B., Adakalić, M., Perović, T. (2014a). Olive growing in Montenegro - current state and perspectives. Integrated Protection of Olive Crops IOBC-WPRS Bulletin, 108, 3-11.

Lazović, B., Adakalić, M., Perović, T. (2014b). Clonal Variability of Montenegrin Olive Variety 'Zutica'. Acta Horticulturae, 1057, 501-507. https://doi.org/10.17660/ActaHortic.2014.1057.63

Lazović, B., Adakalić, M., Pucci, C., Perović, T., Bandelj, D., Belaj, A., ... Baldoni, L. (2016). Characterizing ancient and local olive germplasm from Montenegro. Scientia Horticulturae, 209, 117-123. https://doi.org/10.1016/j.scienta.2016.06.022

Lazović, B., Bošković, R., Gašić, K., James, C., Tobutt, K. (2002). Genetic diversity of olives grown along the coast of Montenegro. Acta Horticulturae, 586, 167-170. https://doi. org/10.17660/ActaHortic.2002.586.28

Lazović, B., Bučar-Miklavčić, M., Adakalić, M., Butinar, B., Bešter, E. (2011). Characterization of oil of some olive varieties from Montengro. Proceedings of Olivebioteq Oct. $3^{1 s t}$ Nov. ${ }^{4 \text { th }}$. 2011. Chania. Crete. Greece. (pp. 607-613).

Lazović, B., Klepo, T., Adakalić, M., Šatović, Z., Baruca Arbeiter, A., Hladnik, M., ... Bandelj, D. (2018a). Intra-varietal variability and genetic relationships among the homonymic East Adriatic olive (Olea europaea L.) varieties. Scientia Horticulturae, 236, 175-185. https://doi.org/10.1016/j.scienta.2018.02.053

Lazović, B., Perović, T., Adakalić, M. (2018b). Fruit and endocarp properties in relation to intra-varietal morphological diversity of Montenegrin olive variety 'Žutica'. Acta Sciemtarum Polunorum. Hortorum Cultus, 17(2), 71-81. http://www.hortorumcultus.actapol.net/volume17/issue2/17_2_71.pdf

Lopes, M.S., Mendonça, D., Sefc, K.M., Sabino Gil, F., da Câmara Machado, A. (2004). Genetic evidence of intra-cultivar variability within Iberian olive cultivars. HortScience. 39(7): 1562-1565. https://doi.org/10.21273/HORTSCI.39.7.1562

Marra, F.P., Marchese, A., Campisi, G., Guzzetta, G., Caruso, T., Mafrica, R., Pangallo, S. (2014). Intra-Cultivar Diversity in Southern Italy Olive Cultivars Depicted by Morphological Traits and Ssr Markers. Acta Horticulturae, 1057, 571-576. https://doi.org/10.17660/ActaHortic.2014.1057.73

Martins-Lopes, P., Gomes, S., Lima-Brito, J., Lopes, J., GuedesPinto, H. (2009). Assessment of clonal genetic variability in Olea europaea 'Cobrançosa' by molecular markers. Scientia Horticulturae, 123, 82-89. https://doi.org/10.1016/j. scienta.2009.08.001

Minch, E. Microsat. (1997). Version 1.5b: Stanford University Medical center. Stanford. http://hpgl.stanford.edu/projects/ microsat/

Miranović, K. (2006). Maslina (Olea europaea L.). Podgorica: 'Pobjeda'. (ISBN86-309-0222-1).
MONSTAT - Statistical Year Book of Montenegro (2012). Statistical Office of Montenegro. (pp. 262).

Muzzalupo, I., Chiappetta, A., Benincasa, C., Perri, E. (2010). Intra-cultivar variability of three major olive cultivars grown in different areas of central-southern Italy and studied using microsatellite markers. Scientia Horticulturae, 126(3), 324-329. https://doi.org/10.1016/j.scienta.2010.07.014

Muzzalupo, I., Stefanizzi, F., Salimonti, A., Falabella, R., Perri, E. (2009). Microsatellite markers for identification of a group of Italian olive accessions. Scientia Agricola, 66, 685690. http://dx.doi.org/10.1590/S0103-90162009000500014

Noormohammadi, Z., Hosseini-Mazinani, M., Trujillo, I., Belaj, A. (2009). Study of intracultivar variation among main Iranian olive cultivars using SSR markers. Acta Biologica Szegediensis, 53(1), 27-32. http://www.sci.u-szeged.hu/ABS

Omrani-Sabbaghi, A., Shahriari, M., Falahati-Anbaran, M., Mohammadi, S.A., Nankali, A., Mardi, M., Ghareyazie, B. (2007). Microsatellite markers based assessment of genetic diversity in Iranian olive (Olea europaea L.) collections. Scientia Horticulturae, 112(4), 439-447. https://doi. org/10.1016/j.scienta.2006.12.051

Peakall, R., \& Smouse, P.E. (2006). GENALEX 6: genetic analysis in Excel. Population genetic software for teaching and research. Molecular Ecology Notes, 6, 288-295. https://doi. org/10.1111/j.1471-8286.2005.01155.x

Rallo L. (2005). Variedades de olivo en España. In: Libro primero: Elaiografía Hispánica: Barranco D, Trujillo I, Rallo L. Junta de Andalucia. MAPA and Ediciones Mundi-Prensa. Madrid. (pp. 47-231).

Rao, R., La Mura, M., Corrado, G., Ambros, O., Foroni, I., Perri, E., Pugliano, G. (2009). Molecular diversity and genetic relationships of southern Italian olive cultivars as depicted by AFLP and morphological traits. The Journal of Horticultural Science and Biotechnology, 84(3), 261-266. http://dx.doi.org /10.1080/14620316.2009.11512514

Rohlf, F.J. (1998). NTSYS: numerical taxonomy and multivariate analysis system. Version 2.0. Applied Biostatistics Inc. Setauket. New York.

Rony, C., Baalbaki, R., Kalaitzis, P., Talhouk, S.N. (2009). Molecular characterization of Lebanese olive germplasm. Tree Genetics \& Genomes, 5, 109-115. https://doi.org/10.1007/ s11295-008-0170-0

Rotondi, A., Magli, M., Ricciolini, C., Baldoni, L. (2003). Morphological and molecular analyses for the characterization of a group of Italian olive cultivars. Euphytica, 132, 129-137 https://doi.org/10.1023/A:1024670321435

Sanz-Cortés, F., Parfitt, D.E., Romero, C., Struss, D., Llácer, G., Badenes, M.L. (2003). Intraspecific olive diversity assessed with AFLP. Plant Breeding, 122, 173-177. https://doi. org/10.1046/j.1439-0523.2003.00808.x

Schuelke, M. (2000). An economic method for the fluorescent labelling of PCR fragments. Nature Biotechnology, 18, 233234. http://dx.doi.org/10.1038/72708

Sefc, K.M., Lopes, M.S., Mendonça, D., Rodrigues Dos Santos, M., Laimer Da Câmara Machado, M., Da Câmara Machado, A. (2000). Identification of microsatellite loci in olive (Olea europaea L.) and their characterization in Italian and Iberian olive trees. Molecular Ecology, 9(8), 1171-1173. https://doi.org/10.1046/j.1365-294x.2000.00954.x 
Strikić, F., Bandelj Mavsar, D., Perica, S., Čmelik, Z., Šatović, Z., Javornik, B. (2009). The main Croatian olive cultivar. 'Oblica'. shows high morphological but low molecular diversity. The Journal of Horticultural Science and Biotechnology, 84(3), 345-349. https://doi.org/10.1080/14620316.2009 .11512529

Strikić, F., Liber, Z., Bandelj Mavsar, D., Čmelik, Z., Perica, S., Radunić M, ... Šatović, Z. (2011). Intra-cultivar diversity in the Croatian olive cultivar, 'Lastovka'. The Journal of Horticultural Science and Biotechnology, 86(3), 305-311. https:// doi.org/10.1080/14620316.2011.11512765

Taamalli, W., Geuna, F., Temime, S.B., Bassi, D., Daoud, D., Zarrouk, M. (2007). Using microsatellite markers to characterise the main Tunisian olive cultivars 'Chemlali' and 'Chétoui'. The Journal of Horticultural Science and Biotechnology, 82(1), 25-28. https://doi.org/10.1080/14620316.200 7.11512194

Trentacoste, E.R., \& Puertas, C.M. (2011). Preliminary characterization and morpho-agronomic evaluation of the olive germplasm collection of the Mendoza province (Argen- tina). Euphytica, 177, 99-109. https://doi.org/10.1007/ s10681-010-0270-4

Trujillo, I., Ojeda, M.A., Urdiroz, N.M., Potter, D., Barranco, D., Rallo, L., Diez, C.M. (2014). Identification of the Worldwide Olive Germplasm Bank of Córdoba (Spain) using SSR and morphological markers. Tree Genetics \& Genomes, 10, 141-155. https://doi.org/10.1007/s11295-013-0671-3

Wagner, H.W., \& Sefc, K.M. (1999). IDENTITY 1.0. Centre for Applied Genetics. University of Agricultural Sciences Vienna.

Zaher, H., Boulouha, B., Baaziz, M., Sikaoui, L., Gaboun, F., Udupa, S.M. (2011). Morphological and genetic diversity in olive (Olea europaea subsp. europaea L.) clones and varieties. Plant Omics, 4(7), 370-376.

Zohary, D., Hopf, M., Weiss, E. (2012). Domestication of plants in the Old World: The origin and spread of cultivated plants in Southwest Asia, Europe and the Mediterranean Basin. Oxford: Oxford University Press. $4^{\text {th }}$ Edition. https://doi. org/10.1093/acprof:osobl/9780199549061.001.0001 